\title{
A Study on the Correlation between Guangxi - ASEAN Trade and Guangxi Logistics Growth
}

\author{
Zhigao Liao ${ }^{1, a^{*}}$ and Junli Wang ${ }^{2, b^{*}}$ \\ School of Management, Guangxi University of Science and Technology, Liuzhou, Guangxi, China \\ 545005 \\ a*Liaozhigao@126.com, b873314577@qq.com \\ *The corresponding author
}

Keywords: Guangxi and ASEAN; Growth of logistics; Grey correlation analysis; Advice

\begin{abstract}
Picking the volume of Guangxi - ASEAN trade and the total social logistics in Guangxi in 2002-2014 as time series data, using the grey correlation analysis method to study the relationship between Guangxi - ASEAN trade and the growth of Guangxi logistics. The empirical results show that there is a positive correlation between Guangxi - ASEAN trade and logistics in Guangxi growth, at the same time they show that Guangxi - ASEAN trade has played a stronger role in driving the logistics in Guangxi forward, so to promote the rapid development of Guangxi ASEAN trade is conducive not only to continuing growth of Guangxi logistics, but also to boosting economic growth in Guangxi.
\end{abstract}

\section{Introduction}

As the China-ASEAN FTA officially launched, China's economic and trade with the ASEAN become much more frequently. Guangxi is the only one continental sea even province, bearing much pressure from transportation in incoming and outgoing goods of the ASEAN. Guangxi's first trade partner EU is displaced by the ASEAN after 2002.The Guangxi-ASEAN volume of trade from $\$ 6.279$ billion in 2002 up to $\$ 19.88601$ billion in 2014,by an average of $26.98 \%$ rapid growth a year. Meanwhile the Guangxi's total value of social logistics goods by an average of $15.17 \%$ growth a year. These data well display Guangxi-ASEAN's trade plays important role in Guangxi logistics continued to grow rapidly. So this article uses grey correlative analysis to analysis the relation of Guangxi-ASEAN trade and the growth of Guangxi's logistic, exploring Guangxi-ASEAN's trade plays an important role in the growth of Gunagxi's logistic.

Grey Correlative Analysis. Grey correlative analysis is a kind of statistical analysis techniques, mainly used to analysis the close relation of mother factors and sub factors to determine the main factors that causes changes in the system development is main factors or secondary factors. That is comparative analysis method quantify system dynamic development trend. Compared with traditional analysis methods of mathematical statistics(such as regression analysis analysis of variance. the PCA method), not only the gray correlative analysis is also applicable to the number of the sample or samples have regular, but also need little account amount. This techniques will not have the describe discrepancy of qualitative analysis result and quantitative analysis results, which make up for the defects caused by using method of mathematical statistics to analysis the system[1].

The following steps of Grey correlative analysis:

The first step: select the reference sequence

$X_{0}=\left(x_{01}, x_{02}, x_{03}, \ldots, x_{013}\right)$

Comparative sequence

$$
X_{i}=\left(x_{i 1}, x_{i 2}, \ldots, x_{i 13}\right) \text {, including } i=1,2,3, \cdots, n
$$

The second step: Applies dimensionless method to variable. The commonly used processing 
methods such as the method of initial-valuevaveraging method .This article use the method of initial-value,

$$
X_{i}{ }^{\prime}=X_{i} / x_{i 1}=\left(x_{i 1}{ }^{\prime}, x_{i 2}{ }^{\prime}, \cdots, x_{i n}{ }^{\prime}\right), i=0,1,2, \cdots, m
$$

The third step: find difference sequences 、 maximum differential minimum differential difference sequences:

$$
\Delta_{0 i}(k)=\left|x_{0}{ }^{\prime}(k)-x_{i}^{\prime}(k)\right|, k=1,2, \cdots, n
$$

maximum differential:

$$
M=\operatorname{Max}_{i} \operatorname{Max}_{k} \Delta_{i}(k)
$$

minimum differential:

$$
m=\operatorname{Min}_{i} \operatorname{Min}_{k} \Delta_{i}(k)
$$

The forth step: Calculation of correlation coefficient

$$
\begin{aligned}
& r\left(x_{0}(k), x_{i}(k)\right)=(m+\rho M) /\left(\Delta_{0 i}(k)+\rho M\right), \rho \in(0,1) \\
& K=1,2, \cdots, n i=0,1, \cdots, m
\end{aligned}
$$

Among $\rho$ is identification coefficient, take $\rho=0.5$.

The fifth step: find correlation degree

$$
r\left(x_{0}, x_{i}\right)=\frac{1}{n} \sum_{k i=1}^{n} r\left(x_{0}(k), x_{i}(k)\right), i=0,1,2, \cdots, m \text { 。 }
$$

The sixth: analysis result

$$
r\left(x_{0}, x_{i}\right)>r\left(x_{0}, x_{j}\right)>r\left(x_{0}, x_{k}\right) \cdots>r\left(x_{0}, x_{z}\right) \text {, show } x_{i} \text { precede }{ }^{x_{j}},{ }^{x_{j}} \text { precede }{ }^{x_{k}} \text {, The rest by }
$$
analogy. $x_{i}>x_{j}>x_{k} \cdots>x_{z}$.The $x_{i}>x_{j}$ express that gray correlation degree of $x_{i}$ for the reference sequence $x_{0}$ is greater than ${ }^{x_{j}}$. The greater the degree of association, indicating that the stronger the close between the group factor and the female factors [2].

\section{Guangxi -ASEAN Trade and Logistics Growth Relationship Analysis}

The Development of Guangxi-ASEAN Trade. (1)Analysis of Guangxi and ASEAN Countries Import and Export Trade

The import and export trade growth is one of the most important symbols of the level of cooperation of bilateral economic and trade. The volume of Guangxi-ASEAN trade increased from $\$ 627.9$ million in 2002 to $\$ 2014$ in 19.88601 billion, with a high rate of $26.98 \%$ growth at an average annual, which is a leap-forward development both in terms of quantity and speed. The export trade reached $\$ 24.33004$ billion in 2014, up 30.2\% over the previous year, and the import reached $\$ 16.22301$ billion in 2014 , up $14.8 \%$ over the previous year, and which remained surplus. With constant expansion and gradually deepening of bilateral economic and trade cooperation between Guangxi and ASEAN, ASEAN is playing an increasingly active role in the structure of Guangxi foreign trade, the proportion of the import and export trade of Guangxi and ASEAN countries is constantly improved in Guangxi foreign trade. Which improved from $25.84 \%$ in 2002 to $49.04 \%$ in 2014, ASEAN had overtaken Hong Kong as the first partner of Guangxi in foreign trade, thus it can be seen that, the establishment of China-ASEAN free trade zone provides 
favorable conditions for accelerating development of Guangxi-ASEAN trade, and the development of Guangxi-ASEAN trade increases year by year ${ }^{[3]}$.

From the table one, Guangxi-Asean tade Trade import and export in the speed of $37.1 \%$ growth even through the impact of subprime crisis in 2008 come into financial crisis, especially the export in the speed of $56.8 \%$ and import maintain $8 \%$ growth.Guangxi guangxi reached $30 \%$ in the proportion of the total import and export of the association of ASEAN.

Through the export receding in 2009 and 2010, the export keep the high growth trend from $48.7 \%$ in 2011 to $49.04 \%$ in 2014. So the global financial ceisis have less impact on the trade of Guangxi-Asean. In the 2014, the establishment of Guangxi-ASEAN FTA have been for four years, following many products of both sides added into zero-tariff ranks, the FTA have already get into smooth development ${ }^{[4]}$.

Table $1 \quad 2002$-2014 Guangxi and ASEAN trade volume

\begin{tabular}{llllllll}
\hline Year & $\begin{array}{l}\text { Export } \\
\text { Amount } \\
\text { (Million } \\
\text { USD) }\end{array}$ & $\begin{array}{c}\text { Export } \\
\text { s year year } \\
(\%)\end{array}$ & $\begin{array}{l}\text { Import } \\
\text { Amount } \\
\text { (Million } \\
\text { USD) }\end{array}$ & $\begin{array}{l}\text { Import } \\
\text { year on } \\
\text { year } \\
(\%)\end{array}$ & $\begin{array}{l}\text { Import } \\
\text { Export } \\
\text { Amount } \\
\left(\begin{array}{l}\text { Milliond } \\
\text { USD })\end{array}\right.\end{array}$ & $\begin{array}{l}\text { Import } \\
\text { and } \\
\text { Export } \\
\text { year } \\
\text { year }(\%)\end{array}$ & $\begin{array}{l}\text { On the region's } \\
\text { ondal imports } \\
\text { and exports } \\
\text { accounted } \\
(\%)\end{array}$ \\
\hline 2002 & 44239 & 69.4 & 18551 & 15.9 & 62790 & 49.1 & 25.84 \\
2003 & 55235 & 24.9 & 27476 & 48.1 & 82711 & 31.7 & 25.91 \\
2004 & 63620 & 15.2 & 36490 & 33.3 & 100110 & 21.1 & 23.34 \\
2005 & 83059 & 30.5 & 39344 & 7.7 & 122404 & 22.2 & 23.6 \\
2006 & 98474 & 18.5 & 84195 & 113.4 & 182669 & 49.1 & 27.37 \\
2007 & 173418 & 76.1 & 117428 & 39.4 & 290846 & 59.1 & 31.4 \\
2008 & 271846 & 56.8 & 126908 & 8 & 398754 & 37.1 & 30 \\
2009 & 361729 & 33 & 133044 & 5.4 & 494773 & 24.3 & 34.8 \\
2010 & 458835 & 26.8 & 193724 & 45.6 & 652559 & 31.9 & 36.86 \\
2011 & 682493 & 48.7 & 273331 & 41.1 & 955823 & 46.5 & 40.97 \\
2012 & 933744 & 36.8 & 271121 & -0.8 & 1204865 & 26.1 & 40.88 \\
2013 & 1258390 & 34.8 & 333086 & 22.9 & 1591475 & 32.1 & 48.47 \\
2014 & 1707300 & 35.7 & 281300 & -15.5 & 1988600 & 25.0 & 49.04 \\
\hline
\end{tabular}

As mentioned above, The association of ASEAN in guangxi has improved its status in foreign economic relations and brought a certain test to Guangxi logistics and economy. At present, the ASEAN palys more and more crucial role to the health of Guangxi foreign trade sustainable development.At the same time, with Guangxi -ASEAN bilateral trade cooperation and expanding gradually, its bilateral trade status in each other's future will continue to improve, even have more important influence on each other.

(2)Guangxi- ASEAN Countries Trade Mode Analysis

Guangxi as "bridgehead" of China-ASEAN has unique advantages to develop bilateral trade. Guangxi have $1020 \mathrm{~km}$ common boundary that has 17 first-class port、8second-class port and 25 border trade points with ASEAN. Its unique geographical location and convenient port advantage makes the Guangxi border trade with ASEAN cooperation achieved rapid development ${ }^{[5]}$. Bilateral trade cooperation mainly in the form of general trade and frontier trade for a long time.

From table 2 we can find the small-scale border trade takes half percent of Guangxi -ASEAN trade. In 2014, the small-scale border trade up to $\$ 14.728$ billion, takes $74.06 \%$ of the import and export. The export proportion reached $95.12 \%$. The general form trade in Guangxi-ASEAN trade accounted for $14.85 \%$, but the form of processing trade accounts for a small proportion. 
Table 2 The way of bilateral trade between Guangxi and ASEAN in 2014

\begin{tabular}{ccccccc}
\hline \multirow{2}{*}{ Project } & \multicolumn{2}{c}{ Import and Export } & \multicolumn{2}{c}{ Export } & \multicolumn{2}{c}{ Import } \\
\cline { 2 - 6 } & $\begin{array}{c}\text { Amount } \\
\text { (BillionUS } \\
\mathrm{D})\end{array}$ & $\begin{array}{c}\text { Propo } \\
\text { rtion } \\
(\%)\end{array}$ & $\begin{array}{c}\text { Amount } \\
(\text { Billion USD) }\end{array}$ & $\begin{array}{c}\text { Propo } \\
\text { rtion } \\
(\%)\end{array}$ & $\begin{array}{c}\text { Amount } \\
(\text { BillionUSD) }\end{array}$ & $\begin{array}{c}\text { Proportion } \\
(\%)\end{array}$ \\
\hline General trade & 29.54 & 14.85 & 13.98 & 47.33 & 15.56 & 52.67 \\
$\begin{array}{c}\text { Processing } \\
\text { Trade }\end{array}$ & 10.78 & 5.42 & 10.58 & 98.14 & 0.20 & 1.86 \\
$\begin{array}{c}\text { Border trade } \\
\text { Other }\end{array}$ & 147.28 & 74.06 & 140.09 & 95.12 & 7.19 & 4.88 \\
Total & 11.26 & 5.66 & 6.08 & 54.00 & 5.18 & 46.00 \\
\hline
\end{tabular}

Small-scale border trade plays a leading role in the Guangxi and ASEAN countries import and export trade mainly because Pingxiang, Longzhou, Daxin of Guangxi border on Vietnam, and the residents between the two countries establish a great relations of border trade by exchanging of needed goods for a long time, at the same time, Vietnam is a leading partner of Guangxi - ASEAN trade, so the small-scale border trade has become the main way of trade. In addition, interest rate discount to small-scale border trade providing by the government of preferential policy, promotes more enterprises to adopt the method of small-scale border trade.

(3)Guangxi and ASEAN Countries Investment Situation Analysis

There is a relatively large gap of economic development among ASEAN countries which results differences on their investment in Guangxi, as shown in table 3 below, the contract amount of Singapore, Indonesia, Thailand, Malaysia is larger than others. By the end of December 2015, there are up to 512 ASEAN investment projects in Guangxi, the contract reaches to $\$ 3.09451$ billion, the actual use $\$ 2.13139$ billion. In the years that followed, with investment projects increasing, the investment amount has expanded, that reached to $\$ 74.12$ million in 2014 alone, although the investment amount was less, but the development is rapid with huge potential. With the growth trend of ASEAN total investment in Guangxi, Guangxi has been making a development. Guangxi relies too much on foreign capital of individual countries, and the investment which is unbalanced is mainly concentrated in the second industry, and the investment mainly flows to the central city and the real estate project ${ }^{[6]}$.The rapid development of Guangxi and ASEAN countries trade drives Guangxi to use the growth of investment of ASEAN in Guangxi, and this development trend is bound to affect the development direction of Guangxi economy and logistics, as well as the development of economy and trade of Guangxi to ASEAN countries.

Table 3 Guangxi directly invest in ASEAN countries cumulative table ended 2016

\begin{tabular}{cccc}
\hline Country & $\begin{array}{c}\text { Number of projects } \\
\text { (unit) }\end{array}$ & $\begin{array}{c}\text { Contracted foreign } \\
\text { investment ( million USD) }\end{array}$ & $\begin{array}{c}\text { Actual utilization } \\
\text { ( million USD) }\end{array}$ \\
\hline Singapore & 197 & 139819 & 102359 \\
Indonesia & 25 & 51018 & 47764 \\
Malaysia & 123 & 59301 & 29857 \\
Thailand & 125 & 32936 & 28925 \\
Vietnam & 24 & 13945 & 1891 \\
Philippines & 11 & 9907 & 1228 \\
Brunei & 6 & 2510 & 1110 \\
Laos & 1 & 15 & 5 \\
Total & 512 & 309451 & 213139 \\
\hline
\end{tabular}


Grey Correlation Analysis of Guangxi - ASEAN Trade on Growth of the Logistics. Based on the total social logistics in Guangxi as a reference sequence $\mathrm{Y}_{0}$, the total volume of Guangxi ASEAN trade $\left(\mathrm{Y}_{1}\right)$, export trade of Guangxi to ASEAN $\left(\mathrm{Y}_{2}\right)$, import trade of Guangxi to ASEAN $\left(\mathrm{Y}_{3}\right)$ are to be comparative data sequences respectively. All the above variables are selected from 2002 to 2014 annual series data, and the capacity of the sample is 13, and all the data are from Guangxi statistical information network (www.gxtj.gov.cn), and dimensionless processing of the original data is made by using the method of initial value.

Table 4 Dimensionless Processing Table

\begin{tabular}{ccccc}
\hline Years & $\begin{array}{c}\text { Total social } \\
\text { logistics(Y) }\end{array}$ & $\begin{array}{c}\text { Import and export } \\
\text { volume of Guangxi to } \\
\text { ASEAN }\left(\mathrm{Y}_{1}\right)\end{array}$ & $\begin{array}{c}\text { Exports of Guangxi to } \\
\text { ASEAN }\left(\mathrm{Y}_{2}\right)\end{array}$ & $\begin{array}{c}\text { Inports of Guangxi to } \\
\text { ASEAN } \\
\left(\mathrm{Y}_{3}\right)\end{array}$ \\
\hline 2002 & 1 & 1 & 1 & 1 \\
2003 & 1.1178 & 1.3169 & 1.2486 & 1.4811 \\
2004 & 1.3605 & 1.5956 & 1.4381 & 1.967 \\
2005 & 1.6012 & 1.9509 & 1.8775 & 2.1209 \\
2006 & 1.8805 & 2.9114 & 2.226 & 4.5386 \\
2007 & 2.3075 & 4.6356 & 3.92 & 6.33 \\
2008 & 2.635 & 6.3467 & 6.1449 & 6.841 \\
2009 & 3.0745 & 7.8858 & 8.1767 & 7.1718 \\
2010 & 3.1317 & 9.9225 & 10.3717 & 10.4428 \\
2011 & 4.0023 & 15.2342 & 15.4274 & 14.734 \\
2012 & 5.5733 & 19.2035 & 21.1068 & 14.6149 \\
2013 & 6.4706 & 25.3654 & 28.4453 & 17.9552 \\
2014 & 7.0947 & 31.6949 & 38.5926 & 15.1636 \\
\hline
\end{tabular}

Through calculating and processing the data in table 4, we get the difference sequence values, as follows:

$\Delta 01=(0,0.1991,0.2351,0.3497,1.0309,2.3281,3.7117,4.8114,6.7909,11.2319,13.6302,18.8948,2$ 4.6002);

$\Delta 02=(0,0.1307,0.0776,0.2763,0.3454,1.6126,3.5100,5.1022,7.2401,11.4251,15.5335,21.9747,3$ 1.4980);

$\Delta 03=(0,0.3633,0.6065,0.5197,2.6580,4.0225,4.2060,4.0973,7.3111,10.7318,9.0416,11.4846,8.0$ 689);

The biggest difference $M=31.4980$, the minimum difference $\mathrm{m}=0$, assuming resolution ratio $\xi=0.5$, grey correlation coefficient and grey correlation can be calculated respectively (see table $5)$.

According to the analysis result, the grey correlation degree can be calculated. $r\left(y_{0}, y_{1}\right)=0.7692, r\left(y_{0}, y_{2}\right)=0.7652, \quad r\left(y_{0}, y_{3}\right)=0.7920$. It follows that: $r\left(y_{0}, y_{3}\right)>r\left(y_{0}, y_{1}\right)>r\left(y_{0}, y_{2}\right)>0.7$

Most of the correlations between Guangxi - ASEAN trade influence factors and the total social logistics in Guangxi are above 0.7, showing that there is a strong correlation between them[7]. It shows that there is a big relevance between Guangxi - ASEAN trade and the growth of Guangxi logistics, and it has a strong positive correlation, also suggests that Guangxi - ASEAN trade has a promoting effect on growth of logistics in Guangxi, is one of the important factors affecting regional transport demand, to some extent stimulating the rapid growth of the logistics in Guangxi. 
Table 5 Grey Correlation and Grey Correlation

\begin{tabular}{cccc}
\hline Years & $r\left[y_{0}(k), y_{1}(k)\right]$ & $r\left[y_{0}(k), y_{2}(k)\right]$ & $r\left[y_{0}(k), y_{3}(k)\right]$ \\
\hline 2002 & 1 & 1 & 1 \\
2003 & 0.9875 & 0.9918 & 0.9775 \\
2004 & 0.9853 & 0.9951 & 0.9629 \\
2005 & 0.9783 & 0.9828 & 0.9681 \\
2006 & 0.9386 & 0.9785 & 0.8556 \\
2007 & 0.8712 & 0.9071 & 0.7965 \\
2008 & 0.8093 & 0.8177 & 0.7892 \\
2009 & 0.766 & 0.7553 & 0.7935 \\
2010 & 0.6987 & 0.6851 & 0.683 \\
2011 & 0.5837 & 0.5796 & 0.5947 \\
2012 & 0.5361 & 0.5034 & 0.6353 \\
2013 & 0.4546 & 0.4175 & 0.5783 \\
2014 & 0.3903 & 0.3333 & 0.6612 \\
\hline
\end{tabular}

\section{Conclusions}

(1)Guangxi - ASEAN trade has a promoting effect on growth of Guangxi logistics

According to the analysis of the grey correlation analysis and regression equation results, Guangxi - ASEAN trade has a strong promoting effect on growth of Guangxi logistics, as the import-export volume of Guangxi - ASEAN trade increased an average of 10000 dollars, and the total social logistics in Guangxi will be an increase of 1.5403 million yuan. But from the view of the influence of demand of logistics in Guangxi under ASEAN and Guangxi bilateral trade, the single trade structure makes Guangxi foreign trade logistics mainly concentrated in the transportation of low level labor intensive commodity and raw products. Guangxi need to constantly optimize the product structure, drive the structure of logistics demand to change, thus changing the current situation of the single structure of Guangxi - ASEAN trade[8]. At the same time, through regression analysis on the bilateral trade volume and the Guangxi logistics demand, we can know that the Guangxi logistics demand scale will be in progress along with the development of Guangxi - ASEAN bilateral trade, also suggests that Guangxi - ASEAN trade not only drive the logistics demand of Guangxi to develop, but also the lack of trade development affects the development of the logistics demand in Guangxi[9]. In 2014 The volume of Guangdong - ASEAN trade reached 112.286 billion US dollars, compared with Guangdong, Guangxi - ASEAN trade was only \$19.886 billion, even less than $\$ 72.6$ billion of Yunnan, so the development of Guangxi logistics demand depends on the promotion of Guangxi - ASEAN bilateral trade volume.

(2)Accelerate the transition to high value-added and high technical trade

Currently Guangxi - ASEAN trade is mainly focus on growth of expansive-number, and goods are mainly lower levels of labor-intensive commodity and raw products with very little proportion of technology intensive and capital intensive products, also the trade type is relatively single. In this trade situation, the demand for logistics is mainly focus on transportation, storage and preservation of raw materials, agricultural products and primary products, for logistics demand of circulating processing and packaging, especially the high value-added is relatively fewer[10].In this condition of trade, Guangxi needs to develop new export growth points, which is high value-added, high technical and of great potential, improving the status of Guangxi - ASEAN trade. 


\section{Acknowledgements}

(1)Guangxi philosophy and social science fund(The grant No.13BGL009)

(2)This research was supported by the outstanding young backbone teachers' training program in higher education institution of Guangxi, China.

\section{References}

[1] Y.Y. Li. Gray correlation analysis of industrial structure and economic growth in Gansu Province [J]. Enterprise Economics, 2011, 05: 20-23.

[2] Y.Y. Pan, Guoxi Song. Guangxi Logistics Demand Forecasting Model Based on Gray System Theory [J]. Journal of Guangxi University of Finance and Economics, 2008, 01: 26-29.

[3] G.C.Chen, Y.L. Jiang and K.Zhou. Relationship between Guangxi-ASEAN trade and Guangxi's economic growth [J]. Guangxi Social Sciences, 2013, 08: 35-38.

[4] Y.C.Liang. Guangxi in China-ASEAN Cooperation: Achievements in the Past Decade and Strategies for the Next Decade [J]. Journal of Guangxi University (Philosophy and Social Sciences), 2015, 01: 71-90.

[5] Y.H. Ding. Guangxi overall liberalization and development strategy must be a big adjustment on Guangxi as the building of China and ASEAN free trade area of the experimental area of countermeasures [J]. Reform and Strategy, 2002, Z2: 29 -32.

[6] C.Y. Chen. Guangxi modern logistics demand analysis and forecast research. Wuhan University of Technology, 2010.

[7] S.F.Liu, H.Cai, Y.J.Yang, Y.Cao. Advances in gray relational analysis model [J]. Systems Engineering-Theory \& Practice, 2013, 08: 2041-2046.

[8] M. Jian and Y.H.Tang. Journal of Guangxi University for Nationalities (Philosophy and Social Sciences Edition), 2009, 03: 125-128.

[9] Hooi Hooi Lean, Wei Huang, Junjie Hong, Logistics and economic development: Experience from China, Transport Policy, Volume 32, March 2014, Pages 96-104.

[10]G.M. Zhang. Guangxi logistics industry association and spillover effects analysis. SAR, 2012, 05: 274-276. 